\title{
Identification of Resistance to the Large Raspberry Aphid in Black Raspberry
}

\author{
Michael Dossett \\ Department of Horticulture, Oregon State University, Corvallis, OR 97331 \\ Chad E. Finn' ${ }^{1}$ \\ U.S. Department of Agriculture-Agricultural Research Service, Horticultural Crops Research Unit, \\ 3420 NW Orchard Avenue, Corvallis, OR 97330
}

\begin{abstract}
ADDITIONAL INDEX wORDS. Amphorophora agathonica, blackcap, Rubus occidentalis, black raspberry necrosis virus, BRNV
Abstract. The large raspberry aphid (Amphorophora agathonica Hottes) is an important vector of viruses in Rubus $\mathbf{L}$. across North America. Although breeding for aphid resistance has long been recognized as an important tool for protecting red raspberries (Rubus idaeus L.) from viral infection, this is the first report of resistance to $A$. agathonica in black raspberry (Rubus occidentalis $\mathrm{L}$.). Seedlings from 132 wild populations of black raspberries, representing the species' native range, were screened for resistance to $A$. agathonica. Strong resistance was found in three of these populations, one from Ontario (ORUS 3778), one from Maine (ORUS 3817), and one from Michigan (ORUS 4109). Resistance to the large raspberry aphid in ORUS 3778 and ORUS 3817 is dominant and appears to be conferred by different genes. We propose that the genes for resistance in ORUS 3778 and ORUS 3817 be designated $\mathrm{Ag}_{4}$ and $\mathrm{Ag}_{5}$, respectively. Resistance to $A$. agathonica in ORUS 4109 also appears to be controlled by a dominant allele at a single locus, but cannot be differentiated from $\mathrm{Ag}_{4}$ at this time.
\end{abstract}

The black raspberry, often called "blackcap," was first domesticated in the 1830s. A member of the Rosaceae, it is diploid $(2 n=2 x=14)$ and belongs to the same subgenus (Idaeobatus) as the red raspberry, with which it readily crosses. Native to eastern North America from New Brunswick to the Carolinas and as far west as Kansas and Nebraska, black raspberries typically are found in disturbed habitats and near forest edges. The black raspberry industry in North America has undergone a slow but steady contraction since the 1920s due in large part to disease and a lack of adapted and resistant cultivars. Today, growers in Oregon, the leading production region, typically see a decline in production after the second harvest and they remove fields after only three to four seasons because of decreased profitability (Halgren et al., 2007). Much of this decline has been associated with aphid-vectored viruses, particularly black raspberry necrosis virus [BRNV (Halgren et al., 2007)], with disease pressure so high that fields often become $100 \%$ infected within a couple of growing seasons (Halgren, 2006).

\footnotetext{
Received for publication 3 June 2010. Accepted for publication 12 July 2010. This project was supported by grants from the USDA-ARS Northwest Center for Small Fruits Research, the USDA-ARS Plant Exchange Office, and the Oregon Raspberry and Blackberry Commission.

We would like to thank Chaim Kempler, Brian Harding, Karen Keller, Mary Peterson, and Ted Mackey for their assistance during the course of this project. We would like to specifically thank Kim Hummer for taking on a major role in writing the successful proposal to the USDA Plant Exploration to collect many of the accessions obtained in this project and for her critical role in organizing and participating in the collection trip. We would also like to thank the following individuals for contributing seed for this project: W. Anderson (Illinois), M. Bathrick (Pennsylvania), C. Brown (New Jersey), P. Byers (Missouri), T. Cuff (Wisconsin), A. Dale (Ontario), R. Davis (New York), R. Geneve (Kentucky), J. Hancock (Michigan), D. Handley (Maine), A. Jamieson (New Brunswick), K. Kellogg (Connecticut), J. Lehman (Indiana), T. Leslie (Ohio), H. Love (Tennessee), J. Luby (Minnesota), C. Mauchline (Pennsylvania), R. Moyer (Virginia), G. Nonnecke (Iowa), M. Retter (Indiana), M. Stanton (Ohio), H. Swartz (Maryland), F. Takeda (West Virginia), E. Thompson (Arkansas), and C. Weber (New York).

${ }^{1}$ Corresponding author. E-mail: Chad.Finn@ARS.USDA.GOV.
}

Breeders have long recognized the importance of aphid resistance in the development of new raspberry cultivars that protect against virus infection (Schwartze and Huber, 1937). In Europe, at least 13 genes for resistance to the aphid Amphorophora idaei Börner (Homoptera: Aphididae) are known (Hall et al., 2009), and five biotypes of the aphid have been described (Hall et al., 2009; McMenemy et al., 2009). Resistance to A. idaei is derived from a variety of sources, including red and black raspberry. Keep (1989) indicated that the use of these resistance genes has been very effective in slowing the spread of aphid-vectored viruses in red raspberry at East Malling, UK. At the Scottish Crop Research Institute (Invergowrie), virus infection rates in plots of resistant cultivars was less than $10 \%$ after 3 years, while $100 \%$ of susceptible plants became infected during the same period (Jones, 1976).

In North America, the primary vector of the raspberry mosaic virus complex is the large raspberry aphid. Resistance to Amphorophora agathonica is conferred by three genes, all from red raspberry. The single dominant gene, $A g_{1}$, is derived from the old UK cultivar Lloyd George (Daubeny, 1966). Genes $\mathrm{Ag}_{2}$ and $\mathrm{Ag}_{3}$ are dominant genes functioning in tandem to confer resistance and are derived from wild Rubus strigosus Michx. populations in eastern Canada (Daubeny and Stary, 1982). Sources of partial resistance to A. agathonica, as evidenced by the ability of aphids to colonize plants in small numbers, have also been identified (Daubeny, 1972; Kennedy et al., 1973), but the levels of resistance are less than that conferred by $A g_{1}$, and so have received little attention. Until the 1990s, there was evidence for only a single biotype of $A$. agathonica (Converse et al., 1971). However, Daubeny and Anderson (1993) described the discovery of an $\mathrm{Ag}_{l}$ resistance-breaking strain in British Columbia, and new sources of resistance to $A$. agathonica are needed, not only to slow the spread of resistant biotypes, but also to help maintain the durability of existing resistance as well.

While black raspberry has been an important source of resistance A. idaei in Europe (Keep and Knight, 1967), strong resistance to $A$. agathonica has not been identified in 
$R$. occidentalis. Efforts to transfer resistance from red raspberry have been slow and have not resulted in any cultivars. The purpose of this study was to identify sources of strong resistance to A. agathonica in wild populations of black raspberry and to determine its inheritance.

\section{Materials and Methods}

Plant materials And aphids. During Summer 2006, friends and colleagues living in eastern North America, within the native distribution of $R$. occidentalis, were solicited to send seed or fruit from wild plants in their area. Additional seed was obtained in 2007 through a similar request and collecting trips across the southern and western edges of the native range (Hall et al., 2009). Through these efforts, seeds were obtained from more than 150 locations across the range, including 27 states and two Canadian provinces. From some locations, seed from multiple maternal clones were sent as separate samples and were kept separate from each other after arrival. From other locations, the seeds represented bulk fruit samples of many individuals (Table 1). Upon arrival, seeds were extracted from the fruit, dried, and stored in a cool dry place until scarification. Seed was also obtained from eight populations held at the National Clonal Germplasm Repository in Corvallis, OR. Seeds were scarified in concentrated sulfuric acid for $45 \mathrm{~min}$ in an ice bath, rinsed with sodium bicarbonate solution (Church and Dwight, Princeton, NJ), soaked for $6 \mathrm{~d}$ in a $3 \mathrm{~g} \cdot \mathrm{L}^{-1}$ calcium hypochlorite solution (Sigma-Aldrich, St. Louis) with an excess of calcium hydroxide (Mallinckrodt, Phillipsburg, NJ), and then planted on moist peat and held at $4{ }^{\circ} \mathrm{C}$ for 8 weeks. Seedling trays were then placed on the mist bench with bottom heat at $24{ }^{\circ} \mathrm{C}$ for germination. After the emergence of their first true leaf, seedlings were planted in 72-cell trays (cell dimensions $4 \times 4 \times 6 \mathrm{~cm}$ ), and then placed in the greenhouse under a 16 -h daylength. When seedlings were $\approx 10$ to $12 \mathrm{~cm}$ tall, they were repotted individually and then subjected to screening for aphid resistance in the greenhouse under similar conditions to those described above. Seedlings were watered regularly and given a liquid fertilizer $(20 \mathrm{~N}-8.7 \mathrm{P}-16.6 \mathrm{~K}$; Scotts, Marysville, $\mathrm{OH})$ once per week throughout this period to promote fast growth and tender tissue attractive to aphids.

Alate and apterous $A$. agathonica were collected from a commercial red raspberry field and were raised in screened cages on the susceptible 'Meeker' red raspberry. Adult aphids from this colony were placed in petri dishes with a detached leaf and moist filter paper to isolate nymphs as they were born. Nymphs were removed from the petri dishes at 12-h intervals for $5 \mathrm{~d}$ and were transferred to virus-free plants of the susceptible black raspberry 'Munger' in a separate cage to ensure that aphids used for screening seedlings did not carry viruses from the field. This colony was maintained in a screened cage in the greenhouse under a 16-h daylength for the duration of the project. All aphids used in resistance screening came from this colony.

Aphid Resistance SCReening. Between June and Aug. 2007, 5415 seedlings were screened for resistance to A. agathonica in the greenhouse. An additional 1140 wild seedlings were screened for resistance between Feb. and Apr. 2008. We began screening 72 seedlings from each seed lot for resistance, but quickly determined that seed lots could be adequately sampled for resistance with only 36 seedlings. Thus, in 27 seed lots, 72 seedlings were screened for resistance to A. agathonica, and in 151 seed lots, up to 36 seedlings were screened. Some seed lots experienced poor germination; in cases where fewer than 36 seedlings were available, all seedlings were screened for resistance. In those populations where seed from different maternal clones at a location were sent as separate samples, 36 seedlings from each were screened for resistance for a total of up to 216 seedlings from some locations. The methods for screening plants for resistance to $A$. agathonica were similar to those previously used by others screening for resistance to aphids in red raspberry (Daubeny and Stary, 1982; Knight et al., 1959). Three apterous adult aphids were placed on the youngest leaves of each seedling and were allowed to remain undisturbed for 1 week. After 1 week, each seedling was examined for evidence of colonization. Plants with more than 10 aphids on them were scored as susceptible and were placed back on the bench. Plants with fewer than 10 aphids were marked and the total number of adult and nymph aphids was recorded before plants were placed back on the bench. Plants with fewer than three aphids had the appropriate number of adult aphids added to them to bring the number up to three. Four days after this initial inspection, this procedure was repeated. Plants assumed to be susceptible during the first inspection were reexamined to confirm susceptibility, while the procedure for plants with fewer than 10 aphids remained the same. This was repeated at 4-d intervals three more times for a total of five challenges. In this manner, plants that continually exhibited a non-preference reaction by supporting fewer than 10 aphids were identified under conditions of extreme aphid feeding pressure.

In Apr. 2008, a colony of Amphorophora rubitoxica Knowlton was started from aphids collected in the field, and was maintained on 'Munger' using the same procedures as outlined above. Single potted plants of 'Munger', ORUS 3778-1, ORUS 3817-1, and ORUS 4109-1 were simultaneously placed in the colony and were monitored over a 2 -week period for colonization. This was repeated three times over the course of the summer to determine whether resistance to $A$. agathonica coincided with resistance to A. rubitoxica. Seedlings from the cross ORUS 4158-2 $\times$ ORUS 3021-2 were also screened for resistance to A. rubitoxica using the same procedures described above for A. agathonica.

F1 POPUlations. Two aphid-resistant seedlings from ORUS 3778 (Simcoe, ON, Canada) and ORUS 3817 (Gardiner, ME) were selected for crossing the following year: ORUS 3778-1, ORUS 3778-2, ORUS 3817-1, and ORUS 3817-2 (a four-digit ORUS number followed by a dash and another number indicates a selection from within that cross). These plants were moved to large pots and were grown in the greenhouse until September, when they were moved outside. In Jan. 2008, these four plants were brought back into the greenhouse, along with potted plants of the susceptible cultivars Munger and Black Hawk. These plants were allowed to break dormancy and flower, at which time crosses between the resistant and susceptible genotypes were performed (Table 2). Fruit and seeds from these crosses were treated as described above and, after 2 weeks drying, were subjected to the same germination procedures. A subset of seedlings from each cross was screened in the greenhouse for resistance to A. agathonica using the procedures described above (Table 2). This procedure was repeated in Jan. 2009 with the single resistant seedling from Bath, MI (ORUS 4109-1), and an aphid susceptible selection, ORUS 3021-1.

BC $_{1}$ Populations. Five seedlings from each of four $F_{1}$ populations ORUS 4153, ORUS 4155, ORUS 4157, and ORUS 4158 were moved to large pots in Sept. 2008. The plants were fertilized weekly with a liquid fertilizer $(20 \mathrm{~N}-8.7 \mathrm{P}-16.6 \mathrm{~K}$; Scott's, Marysville, $\mathrm{OH}$ ) and kept in a warm greenhouse under a 16-h daylength until 21 Nov. 2008 to promote growth and 
Table 1. USDA-ARS PI number, breeding program cross identification (ORUS) number, general provenance, and results from screening 132 wild black raspberry populations for resistance to the North American large raspberry aphid.

\begin{tabular}{|c|c|c|c|c|}
\hline PI no. & ORUS no. & Provenance & Susceptible (no.) & Resistant (no.) \\
\hline 653296 & 4123 & Mentone, AL & 36 & 0 \\
\hline 653327 & 3779 & Litchfield County, CT & 72 & 0 \\
\hline 652976 & 4119 & Clayton, GA & 36 & 0 \\
\hline 653294 & 4120 & Clayton, GA & 36 & 0 \\
\hline 653298 & 4122 & Dahlonega, GA & 36 & 0 \\
\hline Not in GRIN & 3789 & Arenzeville, IL & 6 & 0 \\
\hline 653329 & 3781 & Iroquois County, IL & 70 & 0 \\
\hline 553949 & 3946 & Waukegan County, IL & 4 & 0 \\
\hline 653331 & 3796 & Greene County, IN & 72 & 0 \\
\hline 653335 & 3800 & Greene County, IN & 36 & 0 \\
\hline 653336 & 3801 & southern Indiana & 72 & 0 \\
\hline 652984 & 4126 & Alma, KS & 6 & 0 \\
\hline 653299 & 4124 & Bonner Springs, KS & 27 & 0 \\
\hline 653303 & 4129 & Fort Riley, KS & 10 & 0 \\
\hline 653301 & 4127 & Manhattan, KS & 2 & 0 \\
\hline 651846 & 4130 & Minneapolis, KS & 16 & 0 \\
\hline 653302 & 4128 & Ogden, KS & 3 & 0 \\
\hline 653300 & 4125 & Perry Lake, KS & 3 & 0 \\
\hline 651848 & 3802 & Fayette County, KY & 72 & 0 \\
\hline 653337 & 3803 & Berkshire County, MA & 72 & 0 \\
\hline 653338 & 3804 & Berkshire County, MA & 36 & 0 \\
\hline 653340 & 3807 & Washington County, MD & 72 & 0 \\
\hline 653350 & 3821 & Camden, ME & 72 & 0 \\
\hline 653349 & 3820 & East Vassalboro, ME & 72 & 0 \\
\hline 653347 & 3817 & Gardiner, ME & 0 & 72 \\
\hline 653348 & 3819 & Hallowell, ME & 36 & 0 \\
\hline 651849 & 3815 & Monmouth, ME & 36 & 0 \\
\hline 653345 & 3814 & Orono, $\mathrm{ME}$ & 36 & 0 \\
\hline 653346 & 3816 & West Kennebunk, ME & 72 & 0 \\
\hline Not in GRIN & 4109 & Bath, MI & 35 & 1 \\
\hline Not in GRIN & 4110 & Benton Harbor, MI & 36 & 0 \\
\hline 553765 & 3948 & Fred Russ State Forest, MI & 14 & 0 \\
\hline 553766 & 3949 & Fred Russ State Forest, MI & 8 & 0 \\
\hline Not in GRIN & 4111 & Grand Ledge, MI & 36 & 0 \\
\hline 553764 & 3947 & Oak Grove, MI & 13 & 0 \\
\hline Not in GRIN & 4112 & Okemos, MI & 36 & 0 \\
\hline 653323 & 4149 & Belgrade, $\mathrm{MN}$ & 15 & 0 \\
\hline 653321 & 4148 & $\begin{array}{l}\text { Big Stone Lake National Wildlife } \\
\text { Refuge, MN }\end{array}$ & 29 & 0 \\
\hline 651847 & 4147 & Big Stone Lake State Park, MN & 36 & 0 \\
\hline 653351 & 3823 & Cass County, MN & 36 & 0 \\
\hline 651851 & 3827 & Dakota County, MN & 72 & 0 \\
\hline
\end{tabular}


Table 1. Continued.

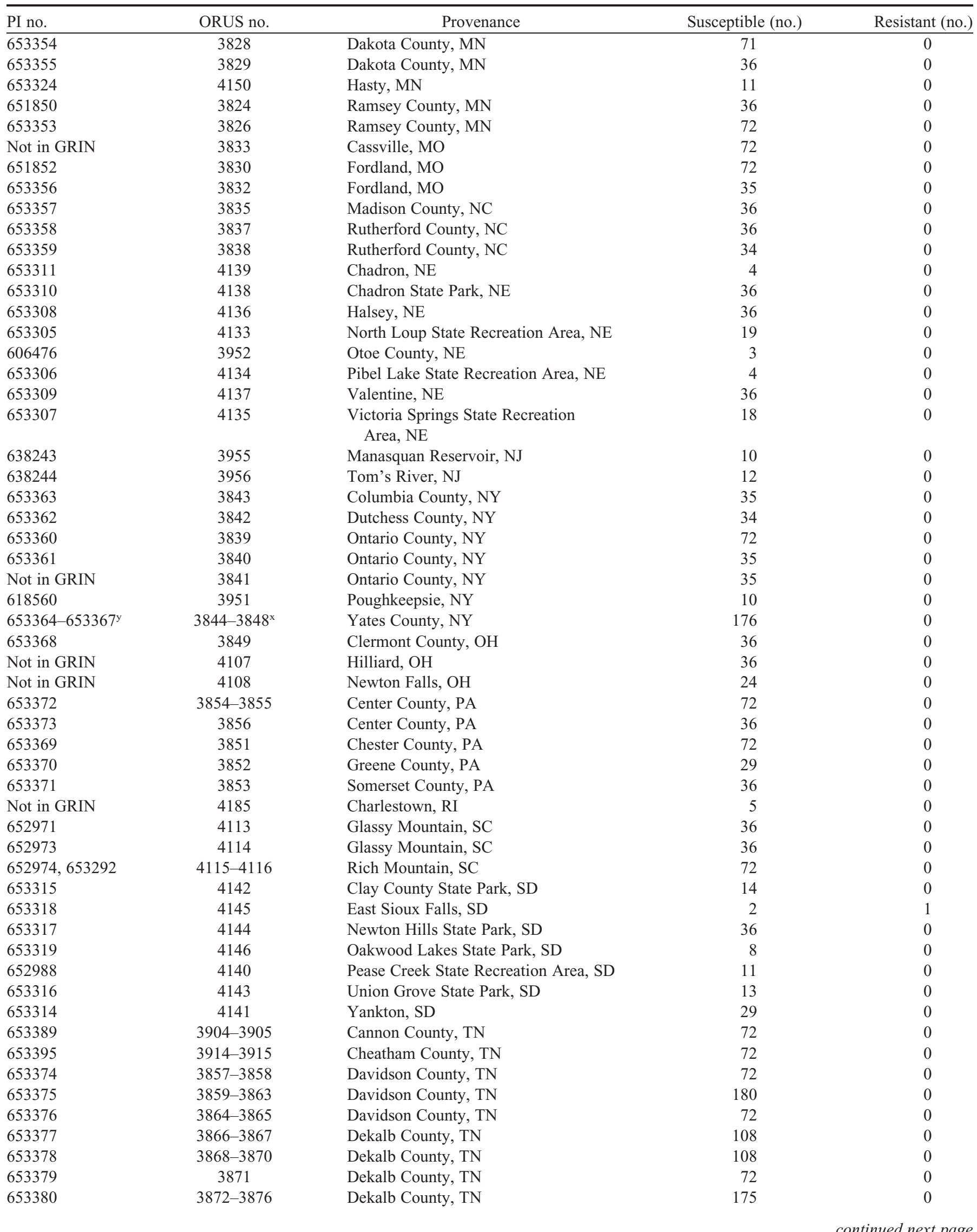


Table 1. Continued.

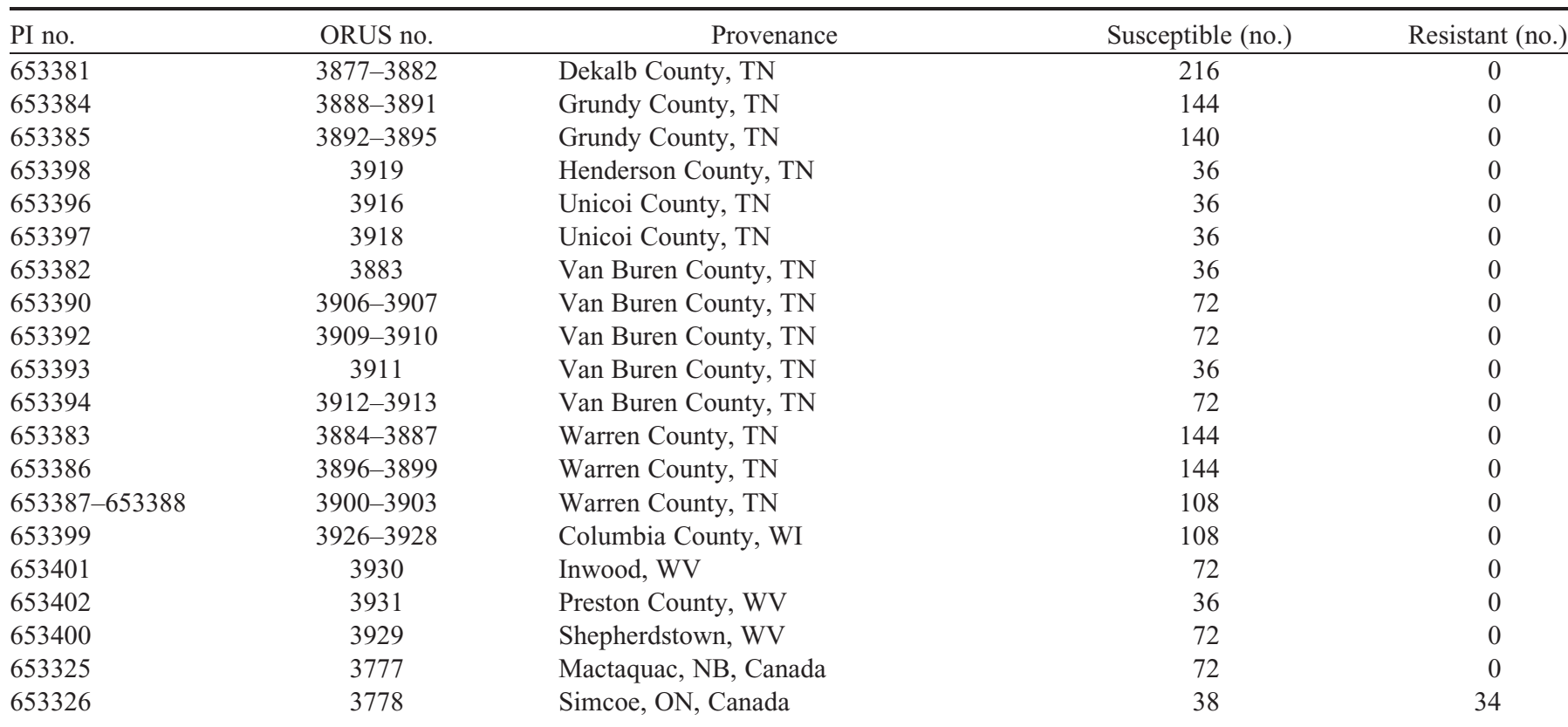

${ }^{\mathrm{z}}$ Accessions not yet available through the USDA, ARS, National Genetic Resources Program, Germplasm Resources Information Network (GRIN).

${ }^{y}$ Multiple PI numbers indicate separate seed lots from this location in GRIN.

${ }^{x}$ Multiple ORUS numbers indicate seed lots from multiple maternal clones at this location were kept and evaluated separately.

Table 2. Summary of crosses in 2008 and 2009 involving black raspberry selections resistant to the North American large raspberry aphid, showing breeding program cross identification (ORUS) numbers and segregation for resistance.

\begin{tabular}{|c|c|c|c|c|c|c|c|c|}
\hline Yr & ORUS no. & Parents & $\begin{array}{c}\text { Postulated genotypes } \\
\text { of parents }\end{array}$ & $\begin{array}{l}\text { Resistant } \\
\text { (no.) }\end{array}$ & $\begin{array}{l}\text { Susceptible } \\
\text { (no.) }\end{array}$ & $\begin{array}{l}\text { Expected } \\
\text { ratio }\end{array}$ & $\begin{array}{l}\text { Chi- } \\
\text { square }\end{array}$ & $P$ \\
\hline 2008 & ORUS 4153 & 'Black Hawk' $\times$ ORUS 3778-1 & $a g_{4} a g_{4} \times A g_{4} A g_{4}$ & 36 & 0 & $1: 0$ & & \\
\hline 2008 & ORUS 4154 & ORUS 3778-2 × 'Black Hawk' & $\mathrm{Ag}_{4} \mathrm{Ag}_{4} \times a g_{4} a g_{4}$ & 18 & 0 & $1: 0$ & & \\
\hline 2008 & ORUS 4156 & 'Munger' × ORUS 3817-1 & $a g_{5} a g_{5} \times A g_{5} A g_{5}$ & 36 & 0 & $1: 0$ & & \\
\hline 2008 & ORUS 4157 & ORUS 3817-1 × 'Black Hawk' & $\mathrm{Ag}_{5} \mathrm{Ag}_{5} \times a g_{5} a g_{5}$ & 54 & 0 & $1: 0$ & & \\
\hline 2008 & ORUS 4158 & ORUS 3817-2 × 'Black Hawk' & $\mathrm{Ag}_{5} \mathrm{Ag}_{5} \times \mathrm{ag}_{5} a g_{5}$ & 18 & 0 & $1: 0$ & & \\
\hline 2009 & ORUS 4304 & ORUS $4158-2 \times$ ORUS $3021-2$ & $\mathrm{Ag}_{5} a g_{5} \times a g_{5} a g_{5}$ & 65 & 37 & $1: 1$ & 7.7 & 0.006 \\
\hline 2009 & ORUS 4305 & ORUS $3021-2 \times$ ORUS $4153-1$ & $a g_{4} a g_{4} \times \mathrm{Ag}_{4} a g_{4}$ & 36 & 36 & $1: 1$ & 0.0 & 1.0 \\
\hline 2009 & ORUS 4306 & 'Jewel' × ORUS 4153-1 & $a g_{4} a g_{4} \times \mathrm{Ag}_{4} a g_{4}$ & 14 & 14 & $1: 1$ & 0.0 & 1.0 \\
\hline 2009 & ORUS 4310 & ORUS $3021-1 \times$ ORUS $4109-1$ & $\mathrm{rr} \times \mathrm{Rr}$ & 36 & 36 & $1: 1$ & 0.0 & 1.0 \\
\hline
\end{tabular}

${ }^{\mathrm{z}} \mathrm{A}$ four-digit ORUS number followed by a dash and another number indicates a selection from within that cross.

maturity. These seedlings were then treated to induce flower bud initiation and dormancy before being brought back into the greenhouse on 1 Apr. 2009 to begin flowering. In early May, crosses were performed between these plants and field-grown plants of ORUS 3021-2 and 'Jewel' (Table 2). Seeds and seedlings from these crosses were treated in the same manner as above and in Dec. 2009, seedlings were screened for aphid resistance as already described.

Statistics. Chi-square tests to determine goodness-of-fit and probability of observed segregation ratios were performed using SAS (version 9.1; SAS Institute, Cary, NC).

\section{Results and Discussion}

Greenhouse inoculation of black raspberry seedlings with A. agathonica and A. rubitoxica resulted in colonization of susceptible plants. Susceptible plants typically supported 20 to
30 aphids after the first week, and a few hundred after 3 weeks. This was observed throughout the course of the screening periods and allowed resistant genotypes to be readily identified.

Table 1 lists the populations screened, their origin, and the number of seedlings found to have strong resistance to A. agathonica. Of the 132 populations screened, strong resistance was confirmed in only three: ORUS 3778, ORUS 3817, and ORUS 4109. In addition, a single seedling from South Dakota, ORUS 4145-1, was tentatively identified as resistant. Due to difficulties propagating this selection, its resistance has not yet been confirmed, and crosses involving ORUS 4145-1 to date have been unsuccessful. Intermediate levels of colonization were noted on one or more plants from several other locations, including ORUS 3827, ORUS 3844, ORUS 3848, ORUS 3854 , ORUS 3855, and ORUS 4124. These may represent sources of quantitative resistance, simply inherited weaker resistance, or may be an artifact of changing environmental conditions and 
aphid populations in the greenhouse during the 3 months in which screening took place. The 34 resistant seedlings of the 72 tested from ORUS 3778 averaged 1.9 aphids per plant after 1 week and 3.5 aphids per plant per inspection over the course of the 23-d screening period (data not shown). All 72 of the seedlings of ORUS 3817 were resistant. After 1 week, these plants averaged 0.9 aphids per plant and averaged 2.1 aphids per plant per inspection (data not shown) over the screening period. The single resistant seedling identified from ORUS 4109 supported no aphids on each of the first four examinations, and was found to have only two aphids on the final examination.

To confirm their resistance, three selections (ORUS 4109-1, ORUS 3778-1, and ORUS 3817-1) and 'Munger' (as a susceptible control) were propagated and five plants of each were screened for aphid resistance in a completely randomized trial. As expected, 'Munger' was the only plant to be colonized in this trial. Monitoring of resistant seedlings of ORUS 3778 and ORUS 3817 in the field in Corvallis, OR, during Spring and Summer 2008 and 2009 failed to detect $A$. agathonica. While $A$. agathonica numbers are fairly low in Corvallis, and vary greatly from year to year, they were found on susceptible black raspberry seedlings in some adjacent plots in 2009, indicating their presence in the field.

Seedlings from the crosses of ORUS 3778-1, ORUS 3778-2, ORUS 3817-1, and ORUS 3817-2 with 'Munger' and 'Black Hawk' were all resistant to colonization by $A$. agathonica when screened in the greenhouse (Table 2). This is consistent with the hypothesis that resistance from these two sources is controlled by dominant alleles and that all four of these resistant selections are homozygous. Crossing these resistant progeny back to susceptible elite germplasm resulted in segregation for resistance to A. agathonica. Both crosses involving resistance originating from ORUS 3778 segregated 1:1 for aphid resistance in the $\mathrm{BC}_{1}$ generation (Table 2), confirming that resistance from this source is controlled by a dominant allele at a single locus. The cross ORUS 3021-1 × ORUS 4109-1 also segregated 1:1 (Table 2), confirming that resistance in ORUS 4109-1 is also controlled by a single dominant gene for which ORUS 4109-1 is heterozygous. Due to a lack of flowers on juvenile plants, only a single $\mathrm{BC}_{1}$ cross involving resistance originating from ORUS 3817 was possible. Progeny of the cross ORUS 4158-2 × ORUS 3021-2 did not segregate 1:1 as expected. Instead, an excess of resistant plants was observed. Nearly $64 \%$ of the progeny from this cross were resistant to colonization by $A$. agathonica. Two possible explanations for this observation are linkage to a lethal recessive allele originating in susceptible grandparents or a gene duplication event creating two loci acting independently to confer resistance in ORUS 4158-2. Susceptibility to colonization by $A$. agathonica in this cross comes from 'Black Hawk' and 'Jewel' as grandparents on opposite sides. If susceptibility were linked to a lethal recessive allele shared by 'Black Hawk' and 'Jewel', this would cause an excess of resistant plants as observed. This scenario seems plausible given that black raspberry cultivars appear to be closely related (Dossett et al., 2010), and that these two cultivars also share a rare recessive allele for non-glaucous canes (Dossett, 2007). Alternatively, duplication of this locus could also cause an excess of resistant progeny similar to that observed by Lunde et al. (2006) in 'Zimmerman' hazelnut and resistance to eastern filbert blight. If the duplicated loci are unlinked, then 3:1 segregation for resistance should be observed. Linkage of the duplicated loci would result in some lesser percentage of resistant progeny, depending on the tightness of the linkage. Further study is needed to determine the exact reason for excess resistant progeny in this cross. Observation of segregation ratios in progeny of siblings of ORUS 4158-2 as well as in crosses involving resistant progeny of ORUS 4158-2 may clarify the cause of this result; however, it is clear from the data presented that resistance to A. agathonica is dominant to susceptibility.

When single plants of the $A$. agathonica-resistant ORUS 3778-1 and ORUS 3817-1 and the susceptible 'Munger' were caged in a colony of $A$. rubitoxica, 'Munger' and ORUS 3778-1 became readily colonized while ORUS $3817-1$ was avoided entirely (data not shown). These results were echoed by observations from an inadvertent infestation of this aphid species in the greenhouse in late September and Oct. 2008. Seedlings of ORUS 3778-1 and ORUS 3778-2 crossed with 'Black Hawk' and 'Munger' became colonized by these aphids and the characteristic chlorotic lesions from their feeding (Stace-Smith, 1954) were present on the leaves. Seedlings of ORUS 3817-1 and ORUS 3817-2 crossed with 'Black Hawk' and 'Munger' remained free of aphids, and chlorotic lesions failed to appear. Testing in Dec. 2009 showed that resistance to $A$. rubitoxica and A. agathonica cosegregated in the cross ORUS $4158-2 \times$ ORUS 3021-2. Amphorophora rubitoxica is not a known virus vector and consequently is of little concern to growers in the Pacific northwestern U.S. However, these results strongly suggest that resistance to $A$. agathonica in ORUS 3778 and ORUS 3817 is controlled by separate genes (designated $\mathrm{Ag}_{4}$ and $\mathrm{Ag}_{5}$, respectively), with $\mathrm{Ag}_{5}$ from ORUS 3817 also conferring resistance to $A$. rubitoxica. Resistance to $A$. agathonica in ORUS 4109-1 is not effective against $A$. rubitoxica and cannot be distinguished from $\mathrm{Ag}_{4}$. A lack of resistance found in the populations collected near this location suggests that resistance in ORUS 4109-1 may be conferred by a unique gene, and further investigation is necessary to determine if this is the case.

The occurrence of resistance to A. agathonica in R. occidentalis is of great value to black raspberry breeders looking for resistance to BRNV and other aphid vectored viruses in North America. While the data suggest the presence of minor gene aphid resistance in some wild black raspberry populations, further study is needed to determine its inheritance and the efficacy of using these sources successfully. Because it only takes a very small number of aphids to colonize plants and spread these viruses, partial resistance may have to be combined from many populations to achieve the desired level of control, and even then may not be sufficient. Work in Scotland has shown that even partial aphid resistance slows the spread of aphid transmitted viruses in red raspberry field plots (Jones, 1976, 1979). However, Stace-Smith (1960) showed that partial resistance was not enough to reduce virus transmission rates in greenhouse experiments with red raspberry.

The use of $\mathrm{Ag}_{4}$ and $\mathrm{Ag}_{5}$ together may increase their durability in new cultivars, reducing the likelihood of new resistancebreaking aphid biotypes from appearing, particularly if used in conjunction with minor gene resistance sources. This is an important consideration. Birch et al. (2005) indicate that every type of major gene aphid resistance in the United Kingdom has been broken while minor gene resistance has remained durable, though less effective. $\mathrm{Ag}_{4}$ and $\mathrm{Ag}_{5}$ are also of potential value to red raspberry breeders as they offer two new sources of resistance that may be incorporated into breeding lines in much the same way as $A_{10}$ (Keep and Knight, 1967). Screening wild black raspberry populations for additional sources of aphid 
resistance is worthwhile. These data suggest that the range has not been exhaustively sampled for diversity. Despite the resistance of all 72 plants sampled from Gardiner, ME, aphid resistance was not detected in three other nearby locations. To date, every source of strong aphid resistance identified in $R$. occidentalis, and nearly all those with some partial resistance, originate in the northern half of the species' range where raspberry aphids are typically more abundant and indicate this area may be a good target for further exploration.

Small quantities of seed from most of the populations studied are available from the USDA-ARS National Clonal Germplasm Repository in Corvallis, OR. Plants of ORUS 3778-1 (PI 658505), ORUS 3817-1 (PI 658506), and ORUS 4109-1 (PI 659143) will also be available by request.

\section{Literature Cited}

Birch, A.N.E., S.C. Gordon, R. Brennan, and A.T. Jones. 2005. Breeding for resistance to the large raspberry aphid: An update on durability of current genes and future prospects. International Organization for Biological and Integrated Control/Western Palearctic Regional Section Bul. 28(10):21-22.

Converse, R.H., H.A. Daubeny, R. Stace-Smith, L.M. Russell, E.J. Koch, and S.C. Wiggans. 1971. Search for biological races in Amphorophora agathonica Hottes on red raspberries. Can. J. Plant Sci. 51:81-85.

Daubeny, H.A. 1966. Inheritance of immunity in the red raspberry to the North American strain of the aphid Amphorophora rubi Kltb. Proc. Amer. Soc. Hort. Sci. 88:346-351.

Daubeny, H.A. 1972. Screening red raspberry cultivars and selections for immunity to Amphorophora agathonica Hottes. HortScience 7: 265-266.

Daubeny, H.A. and A.K. Anderson. 1993. Achievements and prospects: The British Columbia red raspberry breeding program. Acta Hort. 352:285-293.

Daubeny, H.A. and D. Stary. 1982. Identification of resistance to Amphorophora agathonica in the native North American red raspberry. J. Amer. Soc. Hort. Sci. 107:593-597.

Dossett, M. 2007. Variation and heritability of vegetative, reproductive and fruit chemistry traits in black raspberry (Rubus occidentalis L.). MS Thesis, Oregon State Univ., Corvallis.
Dossett, M., N. Bassil, and C.E. Finn. 2010. Transferability of Rubus microsatellite markers to black raspberry. Acta Hort. (In Press).

Halgren, A. 2006. Characterization, epidemiology, and ecology of a virus associated with black raspberry decline. PhD Diss., Oregon State Univ., Corvallis.

Halgren, A., I.E. Tzanetakis, and R.R. Martin. 2007. Identification, characterization, and detection of black raspberry necrosis virus. Phytopathology 97:44-50.

Hall, H., K.E. Hummer, A. Jamieson, S. Jennings, and C. Weber. 2009. Raspberry breeding and genetics. Plant Breed. Rev. 32:39382.

Jones, A.T. 1976. The effect of resistance to Amphorophora rubi in raspberry (Rubus idaeus) on the spread of aphid-borne viruses. Ann. Appl. Biol. 82:503-510.

Jones, A.T. 1979. Further studies on the effect of resistance to Amphorophora idaei in raspberry (Rubus idaeus) on the spread of aphid-borne viruses. Ann. Appl. Biol. 92:119-123.

Keep, E. 1989. Breeding red raspberry for resistance to diseases and pests. Plant Breed. Rev. 6:245-321.

Keep, E. and R.L. Knight. 1967. A new gene from Rubus occidentalis L. for resistance to strains 1, 2, and 3, of the Rubus aphid, Amphorophora rubi Kalt. Euphytica 16:209-214.

Kennedy, G.C., G.A. Schaefers, and D.K. Ourecky. 1973. Resistance in red raspberry to Amphorophora agathonica Hottes and Aphis rubicola Oestlund. HortScience 8:311-313.

Knight, R.L., E. Keep, and J.B. Briggs. 1959. Genetics of resistance to Amphorophora rubi (Kalt.) in the raspberry. I. The gene $A_{1}$ from Baumforth A. J. Genet. 56:261-280.

Lunde, C.F., S.A. Mehlenbacher, and D.C. Smith. 2006. Segregation for resistance to eastern filbert blight in progeny of 'Zimmerman' hazelnut. J. Amer. Soc. Hort. Sci. 131:731-737.

McMenemy, L.S., C. Mitchell, and S.N. Johnson. 2009. Biology of the european large raspberry aphid (Amphorophora idaei): Its role in virus transmission and resistance breakdown in red raspberry. Agric. For. Entomol. 11:61-71.

Schwartze, C.D. and G.A. Huber. 1937. Aphid resistance in breeding mosaic-escaping red raspberries. Science 86:158-159.

Stace-Smith, R. 1954. Chlorotic spotting of black raspberry induced by the feeding of Amphorophora rubitoxica Knowlton. Can. Entomol. $86: 232-235$. 